\title{
Clinical Stage IV Cutaneous Melanoma AJCC v8
}

National Cancer Institute

\section{Source}

National Cancer Institute. Clinical Stage IV Cutaneous Melanoma A/CC v8. NCI Thesaurus. Code C137656.

Stage IV includes: Any T, Any N, M1. M1: Evidence of distant metastasis. (AJCC 8th ed.) 